\title{
Macrosialin Staining Method
}

National Cancer Institute

\section{Source}

National Cancer Institute. Macrosialin Staining Method. NCI Thesaurus. Code C122849.

An immunohistochemical technique used to detect the presence of macrosialin (CD68) in a tissue sample. 